\title{
INTERNAL LOAD OF ELITE MALAYSIAN YOUNG SOCCER PLAYERS IN SMALL SIDED GAMES WITH DIFFERENT PARAMETERS
}

\author{
Pavol Peráček ${ }^{1}$, Matúš Bôžik ${ }^{2}$, Martin Mikulič ${ }^{1}$ \\ ${ }^{1}$ Faculty of Physical Education and Sport, Comenius University in Bratislava, Slovakia \\ ${ }^{2}$ Selangor State Development Corporation Football Club, Malaysia
}

\begin{abstract}
Summary: The aim of the study was to extend the knowledge about the internal load of elite young soccer players in small sided games with different parameters in the category under 19 years. The group consisted of 16 elite soccer players under the age of 19. This team competed in the first league of the same age category We have monitored the time spent by players in bio-energy load zones (percentage of maximum heart rate), in small sided games with 2 players against 2, 3 against 3, with the size of the playing field of $25 \times 18$ meters and $30 \times 25$ meters. We used basic mathematical and statistical characteristics and Wilcoxon t-test for non-parametric selections. Our study confirmed that in the category under 19 years is valid that the larger number of players (3:3) in small sided games, indicates the players to spend more time in bio-energy zones 4 and 5. Direct correlation also applies to the size of the playing field, depending on the time spent in the load zones 4 and 5. The larger dimension of the pitch indicates to more time the players spend in bio-energy load zones, which is considered to be focal for us. If we want to use them as a way of complex training program (game training), then the small sided games are suitable training strategy.
\end{abstract}

Key Words: soccer, internal load, heart rate, small sided games, category under 19 years

DOI 10. 2478/afepuc-2018-0004

(C) Acta Facultatis Educationis Physicae Universitatis Comenianae 


\section{Introduction}

In soccer, there are a lot of technical means and different systems that allow us to better analyse the load of the player in the training and in the match (Prozone, Catapult, Panini Digital, LPM Soccer 3D). From these softwares we can get a lot of data, but we have to sort out them and extract only the ones that are relevant. The coaches should additionally use them and implement them into the coaching process of their teams. An important part of the training process is-the planning, which aims at optimizing the growth of sports performance. However, it is necessary to know the patterns of the training load. That is, the load (training stimulus) stressor must be adequate to make adequate adaptation changes in the player's organism (Bada 2014). One training stimulus at a certain intensity becomes effective only when reaching relevant volume. This does not only apply to the development of motional abilities, but also to the improvement of the technical aspects of game activities. Only with an optimal number of repetitions of the motional coordination, which is characterized by the ideal process of motional activity (Holienka 2005), is strengthened. Randers et al. (2010) found that small forms of soccer have potential in themselves, as an alternative to non-specific means of gaining fitness. If the stressor is more specific, we expect more transfer (high-quality gaming activity) to the match. Owen (2014) also confirms this fact from the point of view of a professional player to whom this specific load has been regularly applied.

In this work we tried to get information about the internal load of players in different small sided games (SSG) with different parameters and in different bio-energy modes of work and how long the players worked. In this direction should the future research be oriented (HillHaas 2011). Through the small sided games, we will achieve the improvement and stabilization of individual gaming activities (Gabbett, Jenkins \& Abernethy 2009), their technical site (Gabbett 2006) and, last but not least, developing the creative potential of the player (Gamble 2004; Owen 2003; Gregson \& Drust 2000; Little 2009). The conditions in the SSG allow creating multiple chains of game activities and game combinations that positively influence the orientation of players in the space, their activity and their emotionalism (Gregson \& Drust 2000; Little 2009). Whether the training process or game load has a decisive role as an adaptive stimulus. A one-off load will cause a one-time training effect. Correct, appropriate and repeated load in the training process brings a cumulative training effect. We must also respect the genetic condition of the players, reflecting on the individual response of the organism to the applied load (Holienka et al. 2012). Adaptation is the result of repeated complex stimuli, reducing the 
response of the organism to given stimuli. It also makes higher performance more economic. From a psychological and sociological point of view, we understand this process as creating certain relationships between personality and the environment. "Adaptation is both a process and a result" (Peráček 2001).

The controversial character of the game forces players to quickly switch from offensive activities to defensive and vice versa, thereby developing their current universal gaming capabilities. This player's ability is deliberately stimulated during various small sided games, when players have to cope with the time and space pressure that their opponent carries out (Engel et al. 2016).

By combining players' behaviour, their various movements in space, and alternating the burden, soccer becomes an unpredictable and highly variable complex of movement elements (Rienzi et al. 2000; Mohr et al. 2008). By properly altering the rules and content of SSG, we meet different goals and tasks. SSG, unlike game exercise, has a monolithic game play (Peráček 2004). In this age category learning improves and in training and enhancing certain physical abilities, the amount of repetition required to successfully handle a game task is reduced. Both motor and sensory motor development are approaching their final form (Vilímová 2002).

We monitored the internal load (heart rate) of players in pre-match games with a different number of players $(2: 2$ and $3: 3)$. We followed the lengths of the time slots during which the players worked in the individual bio-energetic modes of work and are presented in Table 1.

Table 1

Percentage distribution of load zones from maximum heart rate

\begin{tabular}{|c|c|}
\hline \multicolumn{2}{|c|}{ Bioenergetic zone } \\
\hline 1. Recovery zone & $0 \%-62 \% \mathrm{HR} \max$ \\
\hline 2. Endurance zone & $63 \%-73 \%$ HR max \\
\hline 3. Intensive (Aerobic) zone & $74 \%-84 \%$ HR max \\
\hline 4. High-intensity (Threshold) zone & $85 \%-95 \%$ HR max \\
\hline $\begin{array}{ll}\text { 5. } & \text { Maximum (Anaerobic) zone }\end{array}$ & $96 \%-100 \% \mathrm{HR}$ max \\
\hline
\end{tabular}

In SSG, we emphasize the fulfilment of the theory of adequate coverage, either in terms of complexity or in terms of intensity of the training load or from both views at the same time (Peráček 2003). The small sided game (Peráček \& Pakusza 2011) is a continuous game of play, a contradictory character, the players in it are forced to solve the tasks and the game situations in the attack and the defence in time and space disturbance. SSGs are aimed at improving and stabilizing techniques and tactics and developing creativity - it effects adaptively to the 
situational unexpectation and continuous game play - verifying the resilience of individual and collective game performance (Peráček \& Pakusza 2011; Hill-Haas et al. 2011).

\section{Methods}

The aim of the work is to gain knowledge about selected characteristics of the internal load of soccer players in small sided games with different parameters. The survey consisted of 16 elite players up to the 19 years $(18.1 \pm 2$ years $)$ category, with an average body height of $179.3 \pm 8 \mathrm{~cm}$ and an average body weight of $73.8 \mathrm{~kg} \pm 11.8 \mathrm{~kg}$. The team participated in the $1 \mathrm{st}$ Slovak league of the older boys in the category up to 19 years.

Based on the Benson and Connolly tests (2012) we found the maximum heart rate (HR) of the players. Subsequently, using the Polar Team 2 Pro software, we analysed the heart rate of the players during the SSG duration. We have determined individual zones from the maximum heart rate of the players.

We used the Wilcoxon t-test for non-parametric files, to assess the effect of the number of players and the size of the small sided games on time spent in bio-energetics loading zones (zone $4.85 \%$-95 \% HRmax and zone $5.96 \%-100 \%$ HRmax.) we used Effect size by Cohen d (Sigmund \& Frömel 2005).

Table 2

Cohen d-Effect size (Sigmund \& Fromel 2005)

\begin{tabular}{|l|l|}
\hline Small effect & $0,2-0,5$ \\
\hline Medium effect & $0,5-0,8$ \\
\hline Large effect & over 0,8 \\
\hline
\end{tabular}

All statistical hypotheses were evaluated at the significance level of $p<0.05$. This study was approved by the Ethics Commission of the Faculty of Physical Education and Sport of the Comenius University in Bratislava.

\section{Hypotheses}

H1 - We will find, in preparatory games $2: 2$, the significant differences between the time that players pass in the bio-energy zone 4 . and 5. with different dimension of the playground (R1 $\mathrm{R} 2)$

H2 - We will find, in preparatory games 3:3, the significant differences between the time that players pass in the bio-energy zone 4 . and 5 . with different dimension of the playground (R1 - 
R2)

H3 - We will find, in preparatory games with dimension of playground $25 \times 18 \mathrm{~m}$, the significant differences between the time that players pass in the bio-energy zone 4. and 5. in preparatory games with different number of players (S1 - S2).

H4 - We will find, in preparatory games with dimension of playground $30 \times 25 \mathrm{~m}$, the significant differences between the time that players pass in the bio-energy zone 4. and 5 . in preparatory games with different number of players $(\mathrm{S} 1-\mathrm{S} 2)$.

$\begin{array}{lll}\mathrm{S}_{1}\left(\mathrm{R}_{1}\right) & \leftrightarrow & \mathrm{S}_{1}\left(\mathrm{R}_{2}\right) \\ \mathrm{S}_{2}\left(\mathrm{R}_{1}\right) & \leftrightarrow & \mathrm{S} 2\left(\mathrm{R}_{2}\right) \\ \mathrm{R}_{1}\left(\mathrm{~S}_{1}\right) & \leftrightarrow & \mathrm{R} 2\left(\mathrm{~S}_{1}\right) \\ \mathrm{R}_{1}\left(\mathrm{~S}_{2}\right) & \leftrightarrow & \mathrm{R} 2\left(\mathrm{~S}_{2}\right)\end{array}$

$\mathrm{S} 1-2: 2$ (four players excluding goalkeepers)

$\mathrm{S} 2-3: 3$ (six players excluding goalkeepers)

$\mathrm{R} 1-25 \times 18$ meters

$\mathrm{R} 2-30 \times 25$ meters

\section{The procedure of research}

The research situation was in the measuring of the heart rate of soccer players during six repetitions in the 2:2 and 3:3 small sided games with a playground of $25 \times 18 \mathrm{~m}$ (Fig. 1, Fig. 2). We have monitored the time they spend in designated load zones. The load interval was 2 minutes. The rest interval between repetitions was 4 minutes. We repeated both SSG six times. Players have been given instructions on the rules of the SSG (Players cannot pass the ball to their own goalkeeper. The team which gets the ball out of the pitch, loses the ball and the opponent goalkeeper stars the game.).

The values of player's heart rate were written to the collector sheet (Tab. 3).

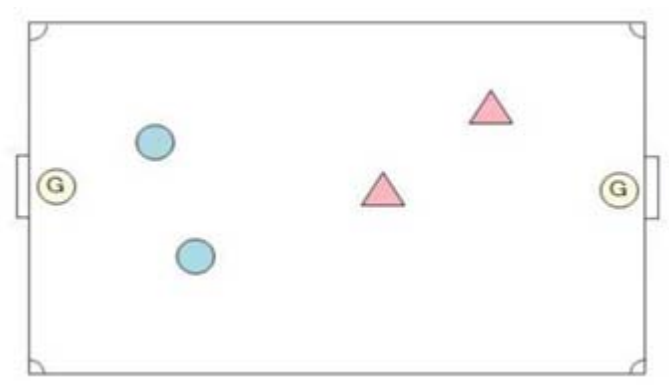

Fig. 1

Example SSG 2:2 - 25x18m (30x25 m)

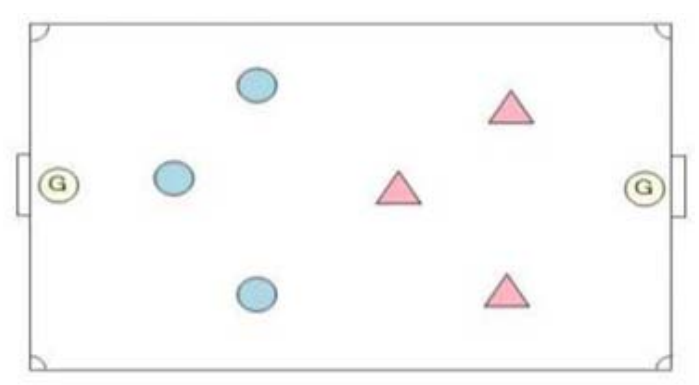

Fig. 2

Example SSG 3:3 - 25x18 m (30x 25 m) 
Table 3

Collector Sheet for HR recording

\begin{tabular}{|c|c|c|c|c|c|c|c|c|c|c|c|c|}
\hline SSG & HRmax & \multicolumn{7}{|c|}{ Time in zones (s, \%) } & \\
\hline $\mathbf{2 5 x 1 8}$ & & $0 \%-62 \% \%$ & $63 \%-73 \%$ & \multicolumn{2}{|c|}{$74 \%-84 \%$} & \multicolumn{2}{c|}{$85 \%-95 \%$} & \multicolumn{2}{c|}{$96 \%-100 \%$} \\
\hline & & Time & Percent & Time & Percent & Time & Percent & Time & Percent & Time & Percent \\
\hline 1. repeat. & & & & & & & & & & & \\
\hline 2. repeat. & & & & & & & & & & & \\
\hline 3. repeat. & & & & & & & & & & & \\
\hline 4. repeat. & & & & & & & & & & \\
\hline 5. repeat. & & & & & & & & & & & \\
\hline 6. repeat. & & & & & & & & & & & \\
\hline Total & & & & & & & & & & & \\
\hline Average & & & & & & & & & & & \\
\hline
\end{tabular}

\section{Results}

The comparison of SSG 2:2 with different dimensions of the pitch indicates that the smaller size of the playing field $(25 \times 18 \mathrm{~m})$ is more intensive for the players, respectively they spend more time in the bio-energetics zone 5 (96 \% - $100 \%$ HR max) (33.04 \% of the total time), during which SSG was played.

From the point of view of intensification, in the training process, bio-energetic zones 4 and 5 are the most important. We can understand them as game training. We have identified them as key, respectively for the training process in soccer interesting from the point of view of intensification. Comparison of the sum of the recorded times of zones 4 and 5 determines a small sided game with a playing field of $25 \times 18$ meters as a more efficient (Tab. 4), because players spend more than $4 \%$ of the time as in SSG on a playing field size of $30 \times 25$ meters (n.s.). This conclusion we have confirmed by Cohen's $d$, when the effect of the size of the playing field reached the value $\mathrm{d}=0.49$, which means the upper limit of the small effect (Fig. 3 ). We can claim that SSG 2:2 with a size of $25 \times 18$ meters is more effective in terms of achieving the necessary intensity.

Table 4

Comparison of SSG 2:2 with different playing field dimensions

\begin{tabular}{|c|c|c|c|c|c|}
\hline Dimensions of SSG & $\mathbf{1}^{\text {st }}$ zone & $\mathbf{2}^{\text {nd }}$ zone & $\mathbf{3}^{\text {rd }}$ zone & $\mathbf{4}^{\text {th }}$ zone & $\mathbf{5}^{\text {th }}$ zone \\
\hline $25 \times 18 \mathrm{~m}$ & $1,88 \%$ & $6,23 \%$ & $13,73 \%$ & $45,07 \%$ & $33,04 \%$ \\
\hline $30 \times 25 \mathrm{~m}$ & $1,46 \%$ & $10,24 \%$ & $14,22 \%$ & $42,92 \%$ & $31,16 \%$ \\
\hline
\end{tabular}




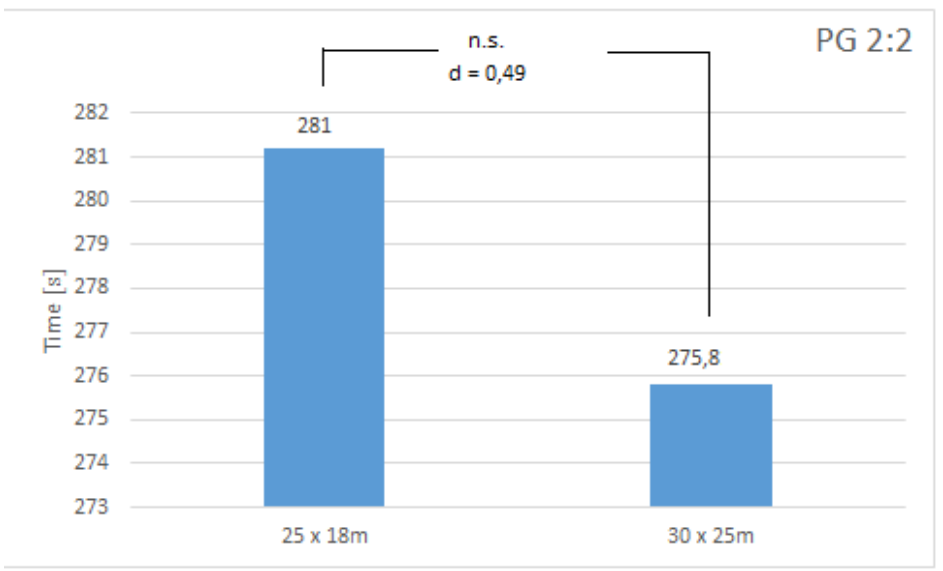

Figure 3

Comparison of SSG 2:2 with different playing field dimensions

Comparison of the dimensions in the small sided games with players 3:3 gave us the opposite result as SSG 2:2 (Tab. 4). In SSG with a size of 30 × $25 \mathrm{~m}$, players perform game activities in load zone 5 by $12.4 \%$ longer time than SSG at $25 \times 18$ meters. The total time in zones 4 and 5 was the difference of $4.4 \%$ (n.s.). We confirmed (Fig. 4) the factual significance by mean Effect size $(\mathrm{d}=0.31)$.

This means that SSG 3:3, measuring 30x25 meters is more efficient in terms of the achievable load intensity.

Table 4

Comparison of SSG 3:3 with different playing field dimensions

\begin{tabular}{|l|l|l|l|l|l|}
\hline Dimensions of SSG & $1^{\text {st }}$ zone & $2^{\text {nd }}$ zone & $3^{\text {rd }}$ zone & $4^{\text {th }}$ zone & $5^{\text {th }}$ zone \\
\hline $25 \times 18 \mathrm{~m}$ & $2,97 \%$ & $9,10 \%$ & $11,85 \%$ & $41,67 \%$ & $34,42 \%$ \\
\hline $30 \times 25 \mathrm{~m}$ & $0,83 \%$ & $8,22 \%$ & $10,44 \%$ & $33,66 \%$ & $46,85 \%$ \\
\hline
\end{tabular}

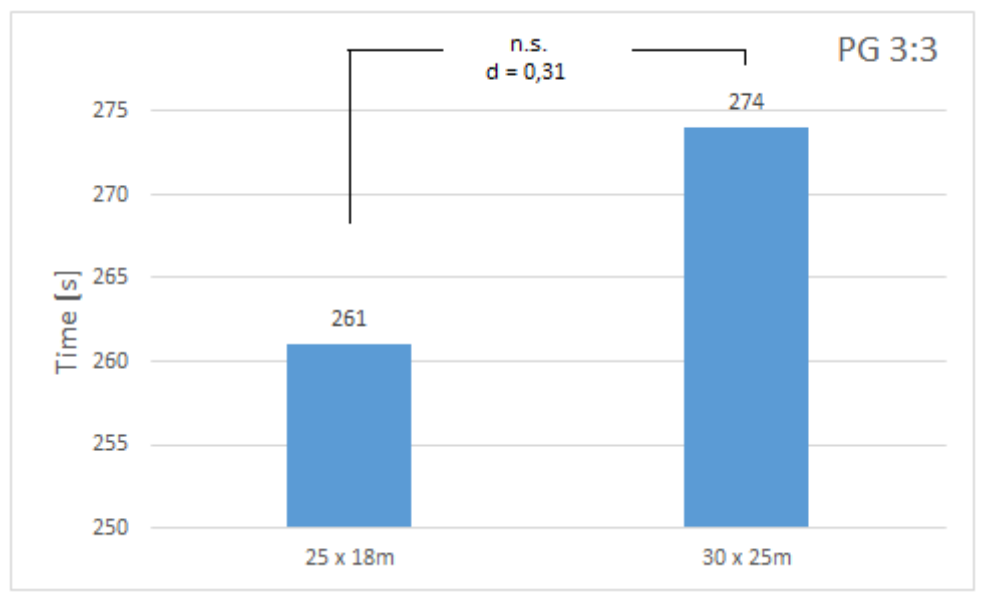

Figure 4

Comparison SSG 3:3 with different playground dimensions 
When comparing SSG 3:3 with SSG 2:2, and the same size of the playing field (25 $\mathrm{x} 18 \mathrm{~m}$ ) it is less effective in terms of load intensity (2:2). Summarising the key zones (No. 4 and 5), players completed $4.6 \%$ more times compared to SSG with a 3:3 player (Tab. 5). Likewise, SSG 2:2 achieved an average rate of action $(d=0.33)$. But in terms of intensity, SSG with six players (3: 3) it is more effective (n.s.), because the players were more times in the most intensive zones (Fig. 5).

Table 5

Comparison of SSG with a size of $25 \times 18 \mathrm{~m}$ with a different number of players

\begin{tabular}{|c|c|c|c|c|c|}
\hline Players & $\mathbf{1}^{\text {st }}$ zone & $\mathbf{2}^{\text {nd }}$ zone & $\mathbf{3}^{\text {rd }}$ zone & $\mathbf{4}^{\text {th }}$ zone & $\mathbf{5}^{\text {th }}$ zone \\
\hline $2: 2$ & $1,93 \%$ & $6,23 \%$ & $13,73 \%$ & $45,07 \%$ & $33,04 \%$ \\
\hline $3: 3$ & $2,97 \%$ & $9,10 \%$ & $11,85 \%$ & $41,67 \%$ & $34,42 \%$ \\
\hline
\end{tabular}

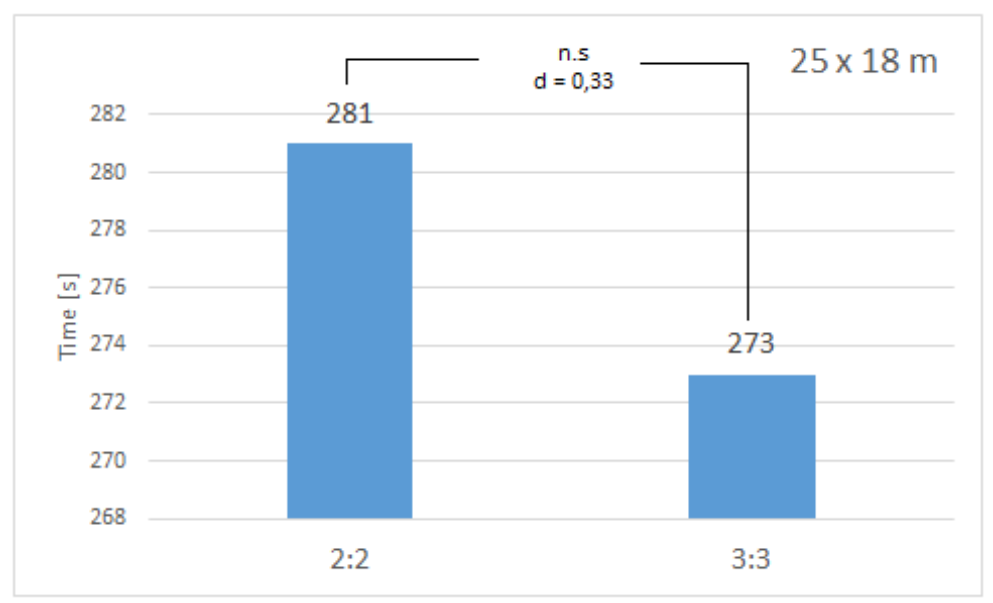

Figure 5

Comparison of SSG with a size of $25 \times 18 \mathrm{~m}$ with a different number of players

SSG with dimensions $30 \times 25$ meters is more effective from the point of view of intensity training load with 3:3 players (Tab. 6). Summarising the two most intensive zones, the difference was only $6.5 \%$ of the total duration of SSG (n.s.). In SSG (3:3) players spent $46.9 \%$ of the time in the highest load zone and compared to SSG (2:2) this represented a difference of almost $7.9 \%$ of the total time (Fig. 6).

Table 6

Comparison of SSG with a size of $30 \times 25 \mathrm{~m}$ with a different number of players

\begin{tabular}{|c|c|c|c|c|c|}
\hline Players & $\mathbf{1}^{\text {st }}$ zone & $\mathbf{2}^{\text {nd }}$ zone & $\mathbf{3}^{\text {rd }}$ zone & $\mathbf{4}^{\text {th }}$ zone & $\mathbf{5}^{\text {th }}$ zone \\
\hline $2: 2$ & $1,88 \%$ & $8,25 \%$ & $13,28 \%$ & $37,66 \%$ & $38,96 \%$ \\
\hline $3: 3$ & $0,83 \%$ & $8,22 \%$ & $10,44 \%$ & $33,66 \%$ & $46,85 \%$ \\
\hline
\end{tabular}




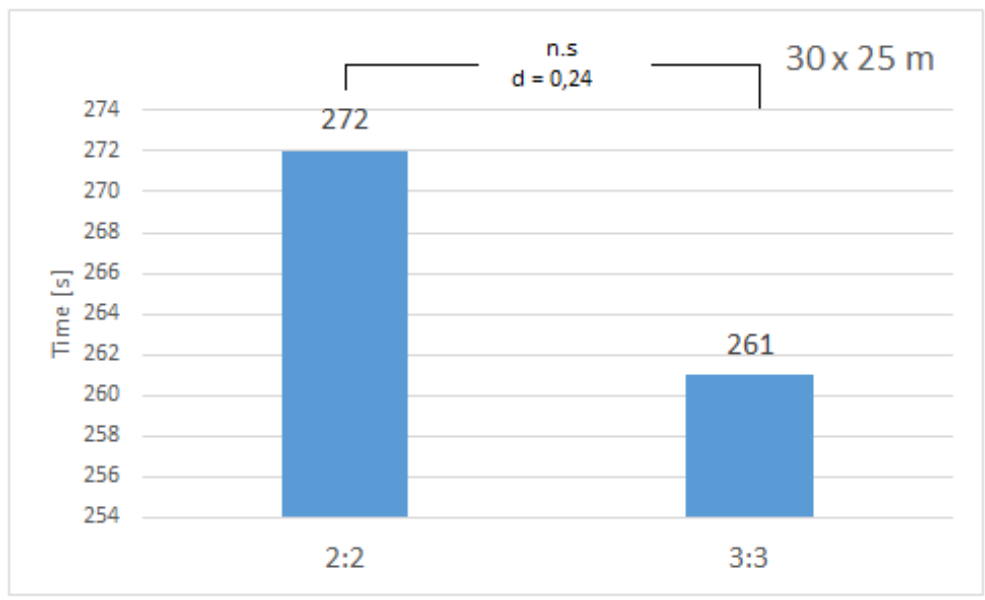

Figure 6

Comparison of SSG with a size of $30 \times 25 m$ with a different number of players

\section{Discussion}

The players under 19 show that the most intensive game $96 \%-100 \%$ of HR max) was SSG 3:3 with a dimension of $30 \times 25$ meters. According to this size and the number of players, they have reached $46.85 \%$ in zone 5 (96\% -100\% of HR max), which is approximately 337 seconds out of a total of 720 seconds. Taking into account this number of players-participating-in this area of $30 \times 25 \mathrm{~m}$, it is necessary to use as much space as possible. In converts to single player, that represents an area of $94 \mathrm{~m}^{2}(10 \times 9.4 \mathrm{~m})$. It is obvious that the players used the most of the field available and were able to put in their performance in terms of intensity, into the highest load zone.

The shortest time in zone 5 (96\% - $100 \%$ of HR max) was recorded in SSG 2:2 with a field dimension of $25 \times 18$ meters. In this SSG, players have performed $33 \%$ of the total time. In absolute figures it represents 238 seconds of total time (720 s).

Most of the time elite players under the age of 19 passed in zone 4 (85\% $-95 \%$ of HRmax) in SSG 2:2 with a playing filed size of 25x18 meters. This value represents $45.07 \%$ (325 seconds) of the total time (720 s). The shortest time in this zone was in SSG 3:3 with a playing filed-size of $30 \times 25$ meters (33.7 \% - 243 seconds).

We have noticed that players in this age category are able to produce the same amount of intensity in each SSG that we've we have chosen, that exactly stimulate the required load, by which we want to influence the players to improve all game activities. The sum of the target load 
zones (4 and 5) for each SSG has represented a minimum value of $76 \%$ (SSG 2:2 - 30 x 25 m). We found that SSG 2:2 (30 x 25 m) and SSG 3:3 (25 x $15 \mathrm{~m})$ stimulate players in terms of time in key bio-energy zones almost identically (difference of 3.8 seconds). As a result, in terms of planning and managing the training process, the coach can manipulate the number of players and dimensions and will in the same time stimulate players in terms of intensity comparatively. Our findings are very important in practice, especially if we do not have the same number of groups and we want to follow the specified training load.

Owen, Twist, and Ford (2004) report that differences in SSG with different numbers of players and also with varying playing filed dimensions, affect the heart rate. Just like us, they were trying to find a SSG that would approach in terms of the pulse rate of the players during the match. They say that during SSG 1:1 and SSG 2:2 they have a more intense heart rate than heart rate during a match. SSG 2:2 are considered in terms of intensity the most intense to the size of $25 \times 20$ meters, which is approximately our size $(25 \times 18)$ at SSG 2:2. In the training process, we also have chosen training instruments that often exceed the intensity of the match. The reason is that the player's organism has adapted to the training load in the match. Consequently, if there is a stimulus in the match, which will be above standard in its bio-energetic requirements, the player's organism will respond appropriately, because it has been repeatedly in the training process with such a stressor.

Abrantes et al. (2012) analysed the internal load of young soccer players in 3:3 and 4:4 small sided games and found similar results to ours most of the time; players spent $85 \%-90 \%$ of the maximum heart rate in the bio-energetic load zones.

Owen et al. (2011) found statistically significant differences between small sided games and large sided games in terms of heart rate. SSGs have been in the $85 \%-95 \%$ and $96 \%-100$ $\%$ zones for longer periods of time than players in SSG with more players. With the results of the authors Owen et al. (2011) who say that with the increasing number of players the intensity of the load decreases, we cannot fully agree on- Because of the playing field dimension of the $30 \mathrm{x}$ 25 meter with a higher number of players (3:3), the intensity has increased. With the results of Owen et al. (2011) we identify only in SSG with dimensions of 25 x 18 m.

One of the factors that greatly affect the heart rate of the players is are the rules. Haas et al. (2010) point to the discovery that even minor changes of the rules in small sided games can significantly affect physiological, spontaneous and time-movement reactions in young elite soccer players. Another possibility to encourage intensification of the training load could be motivation. Authors Rampinini et al. (2007) in their study describes the intensity of the stress in the training process with the influence of the factors such as coaching. They found that coach's 
encouragement affects the load intensity by approximately of $7 \%$.

\section{Conclusion}

Our small sided games in both groups of players $(2: 2,3: 3)$ reached a submaximal and maximum load, where the managing of the training process is becoming an effective from the point of view of the game training and developing tendencies not only in the elite youth but also in senior soccer. It turns out that it is possible, applying specific training stimulus of a complex character, to create a necessary gaming load for players in terms of adequate coverage (both in intensity and in complexity of the training load) despite the fact that the statistically nonsignificant relationship of our hypotheses.

In the summary, small sided games with a different number of players cause elite players of this age category to have a greater response to the player's organism in terms of time spent in the major bio-energetic zones.

This knowledge can be used by trainers in the management and operational planning of the training process. We think that similar training stimulus could help the coaches adequately operate with the training stimulus in elite soccer players of this age category.

The study was funded by the project of the Ministry of Education, Science and Research of Slovak Republic VEGA 1/0529/16: Effectiveness of sports preparation of club and representative basketball teams, depending on age and gender.

\section{References}

1. ABRANTES, C. I., M. I. NUNES, V. M. MAÇÃS, N. M. LEITE, \& J. E. SAMPAIO, 2012. Effects of the number of players and game type constraints on heart rate, rating of perceived exertion, and technical actions of small-sided soccer games. The Journal of Strength \& Conditioning Research, 26(4), 976-981

2. BADA, V., 2014. Ako sa dá predchádzat' chorobám srdca a ciev. Praha: Tigis Print

3. BENSON, R. \& D. CONNOLLY, 2012. Trénink podle srdečni frekvence. Praha: Grada.

4. ENGEL, F., M. PRUS \& N. VIETH, 2016. Jugendfußball: Ausbilden mit Konzept 3. Philippka-Sportverlag

5. GABBETT, T. J., 2006. Skill-based conditioning games as an alternative to traditional conditioning for rugby league players. In: Journal of Strength and Conditioning Research. 20(2), 309. 
6. GABBETT, T., D. JENKINS. \& B. ABERNETHY, 2009. Game-based training for improving skill and physical fitness in team sport athletes. In: International Journal of Sports Science \& Coaching. 4(2), 273-283.

7. GAMBLE, P., 2004. A skill-based conditioning games approach to metabolic conditioning for elite rugby football players. In: The Journal of Strength Conditioning Research. 18.3: 491-497.

8. GREGSON, W. \& B. DRUST, 2000. The physiology of football drills. In: Insight 2000; 3 (4): $1-2$

9. HILl-HAAS, S. V., B. DAWSON, F. M. IMPELlizZERI, \& A. J. COUTTS, 2011. Physiology of small-sided games training in football. In: Sports medicine. 41(3): 199-220.

10. HOLIENKA, M., 2005. Kondičný tréning vo futbale. Peter Mačura-PEEM.

11. HOLIENKA, M. et al., 2012. Tréningové a zápasové zat’aženie hráča v športových hrách. In: Vedecký zborník príspevkov ku grantovej úlohe. Bratislava: ABL PRINT

12. LITTLE, T., 2009. Optimizing the use of soccer drills for physiological development. In: Strength \& Conditioning Journal. 31(3), 67-74.

13. MOHR, $M$ et al., 2008. Match activities in elite woman soccer players at different performance level. In: Journal of strength and conditionong research. 22, 341-349.

14. OWEN, A., 2003. Physiological and technical analysis of small-sided conditioned training games within professional football. Wrexham: SAGE Publications.

15. OWEN, A., C. TWIST, \& P. FORD, 2004. Small-sided games: The physiological and technical effect of altering pitch size and player numbers. Insight. 7(2), 50-53.

16. OWEN, A. L., D. P. WONG, M. MCKENNA \& A. DELLAL, 2011. Heart rate responses and technical comparison between small-vs. large-sided games in elite professional soccer. In: The Journal of Strength \& Conditioning Research. 25(8), 2104-2110.

17. PAIN, M. \& M. OWEN, 2014. Games are where you learn the most. In: The Boot Room. Issue 10, 2014. The FA licensed Coaches' Club Magazines.

18. PERÁČEK, P., 2001. Futbal: riadenie, plánovanie, tréning. 3. vyd. Peter Mačura-PEEM.

19. PERÁČEK, P., 2003. Športové hry. Peter Mačura-PEEM.

20. PERÁČEK, P., 2004. Teória a didaktika športových hier I. Peter Mačura-PEEM.

21. PERÁČEK, P. \& ZS. PAKUSZA, 2011. Futbal. IRIS.

22. RIENZI, E. et al., 2000. Investigation of antropometric and work-rate profiles of elite South American international soccer players, In: Journal Sports Medicine Phys. Fitness. 40(2): 162-169. 
23. SIGMUND, D. \& K. FRÖMEL, 2005. Využití koeficientu Effect size pro posouzení významnosti rozdílú. In: Sborník př́spěvki̊ mezinárodního semináre Pedagogické kinantropologie. Ostrava: KTV PF OU.

24. VILÍMOVÁ, V., 2002. Didaktika tělesné výchovy. Paido. 